\title{
An Investigation of the Impact of State-Owned Enterprise (SOEs) Reform to the Public Value Creation in Indonesia Post-Soeharto Era.
}

\author{
Ubaidillah Nugraha
}

Faculty of Administrative Science, University of Indonesia/ University of Bina Nusantara

ubaidillah.nugraha@ui.ac.id

Abstract

The State Owned Enterprises (SOEs) is important part of the contemporary public sector reform. They'are growing force to the national development and globally by increasing contribution to the global economic and governance (Pricewaterhouse, 2015). In Indonesia, since the era of Old Order (1945-1966), New Order (1966-1998) to Reformasi (1998-current), SOEs have been inseparable instruments in the social and economic development (Mardjana, 1992). Beside their profit motive, SOEs have attributable social benefits for the purpose of public service. The larger the SOE sector, the larger government's direct influence over the public sector (Smith and Trebilcock, 2001). However, SOEs have been associated with major governance cases in Indonesia such as being rigid, bureaucratic and poor services in distributing service to the public and the performances were below average compared to their peers (Chang, 2007; Wicaksono, 2008; Hill, 2000). These circumstances have created a perception of how incompetent the government is in implementing policy (McLeod, 2005) and lead to the minimum aggregate of public value creation. In some SOEs considered a success story, the performance is merely limited to the "business value" creation rather than "public value" creation. SOES reform existed to respond to the problem through variety of reform options and has been considered among critical reform beside beauracratic, decentralization and fiscal reform. The purpose of this paper is to investigate key determinants factors to improve SOEs' capacity in public value creation, specifically from SOEs reform agendas using predominatly several key concepts including of Public Value (Moore, 1995), TIMM (PWc, 2015), Public Sector Reform (Cayden, 1969; ) and through the utilization of Soft Sytems Methodology as the action research approach.

Keywords:Public Value, Public Sector Reform, SOEs, SOEs Reform,Creating Shared Value, Soft System Methodology

\section{INTRODUCTION}

State Owned Enterprise (SOEs)/Badan Usaha Milik Negara $(B U M N)$ according to UU No. 192003 is defined as:

Badan usaha yang seluruh atau sebagian besar modalnya dimiliki oleh negara melalui penyertaan secara langsung yang berasal dari kekayaan negara yang dipisahkan. Kekayaan negara yang dipisahkan adalah kekayaan negara yang berasal dari Anggaran Pendapatan dan Belanja Negara untuk dijadikan penyertaan modal negara pada persero dan/atau Perum serta perseroan terbatas lainnya.

SOEs own dual objective motive both economic objective (profit motive, support economic growth and fiscal sustainability) and public service objective (article 2, UU No: $9,2003)$. SOEs is inseparable part of public sector as a whole, entity whose activities deal with effort to produce goods and services and public service in order to fullfill public need and right (Mardiasmo, 2002).

Picture 1.1

SOEs position in public sector domain

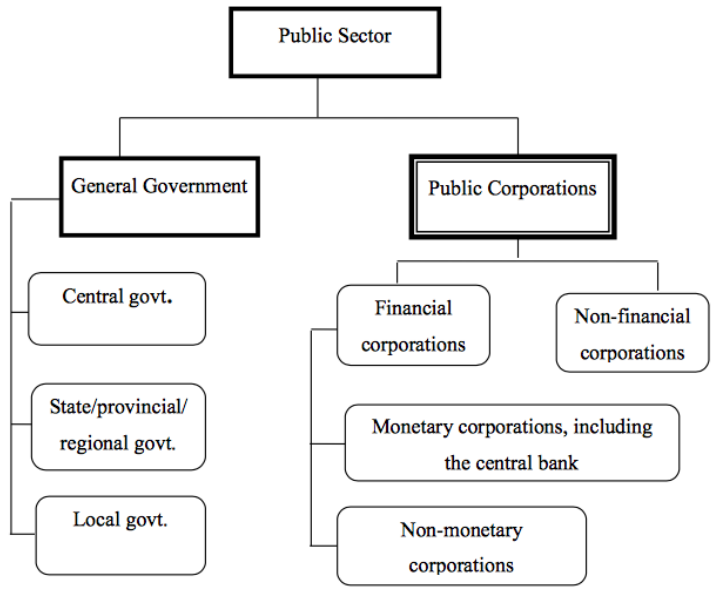

SOEs has been considered as classical as well as contemporary phenomenon. It can be viewed from discussion and debate surrounding its role and responsibility which are existed since the era of 1920 s to date. Started from modest beginning, the presence of SOE is becoming more significant 
nowadays. One of the indicator can be shown from the list of world's biggest enterprise conducted by Fortune Global 500 (please see graph 1.1). In 2005, proportion of SOEs among the 500 top companies is only $9 \%$, ten (10) years later, in 2014, the proportion increase to $24 \%$ (Pricewaterhouse, 2015).

\section{Graphic $1.1^{1}$}

Share of SOEs in list of Fortune 500

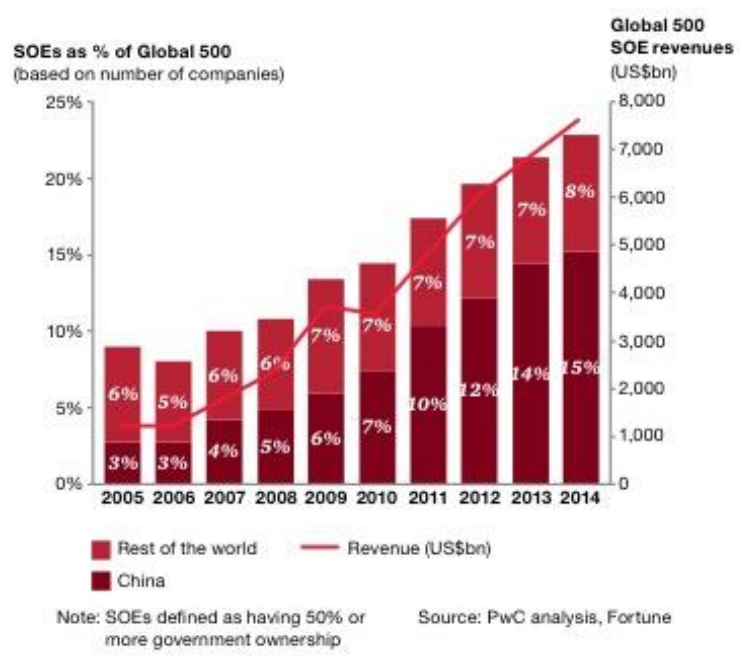

The State Owned Enterprise (SOE) is a key instrument in the Indonesian economy. Since the era of Old Order (1945-1966), New Order (1966-1998) to Reformasi (1998-current), SOEs have been inseparable instruments in the Indonesian social and economic development (Mardjana, 1992). SOEs are the backbone of public infrastructure projects such aa road, port, airport, telecommunication facility, post office (Abeng, 2001). Between 1997 to 1999 , the tax contribution of SOEs achieve $43 \%-59 \%$.

The State-Owned Enterprise (SOE) in developing countries exists due to a mix of political, ideological and economic reasons. Beside their profit motive, SOEs have attributable social benefits for the purpose of public service such as providing methods for income distribution or maintaining employment. The larger the SOE sector, the larger government's direct influence over the public sector (Smith and Trebilcock, 2001). There are currently 139 enterprises managed by the Ministry of SOE with accumulated assets representing $40 \%$ of the Gross Domestic Product (GDP) and employing almost one million staff. The reform in Indonesian social and economic development has been implemented hand in hand with SOEs Reform which has been conducted through ministry of SOEs.

Historically, SOEs are privileged because they have been protected by the government to sell goods and services to the

${ }^{1}$ Fortune 500 is a list of world's biggest enterprise in term of aset size. Pricewaterhouse Cooper, a global consulting firm utilize fortune 500 as a reference to see the development of SOEs, written in the report tittled "StateOwned Enterprise: Catalyst for Public value Creation? (2015)". public. Unfortunately, they have been associated with major corruption cases in Indonesia, being rigid, bureaucratic and poor services in distributing service to the public (Chang, 2007). There has been a significant value destruction of SOEs due to corruption and inefficiency (Abeng, 2001).

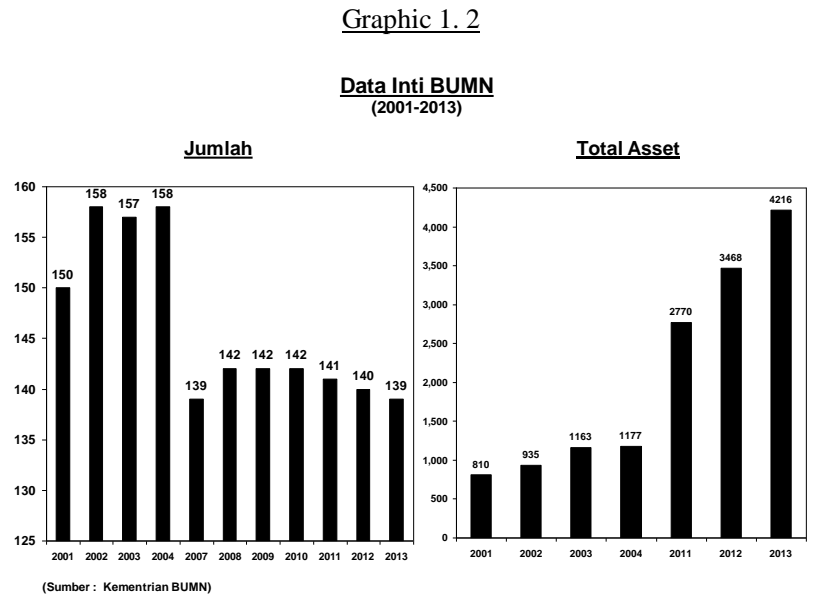

The SOEs performances were below average compared to their peers. They are ranked poorly in various ratings on corporate governance (Wicaksono, 2008) and continue to struggle with low profitability, overstaffing, unfocussed operations and poor productivity (Hill, 2000). Moreover they encountered tremendous challenges in managing the competitive advantage situation especially towards the competition from both private and multinational companies. Inefficiency has flourished in many state-owned enterprises. These kinds of circumstances have created a perception of how incompetent the government in regard to the policy implementation (McLeod, 2005) and lead to the minimum public value creation. In some SOEs considered as success story, the performance is merely limited to the "business" performance rather than "public service" performance.

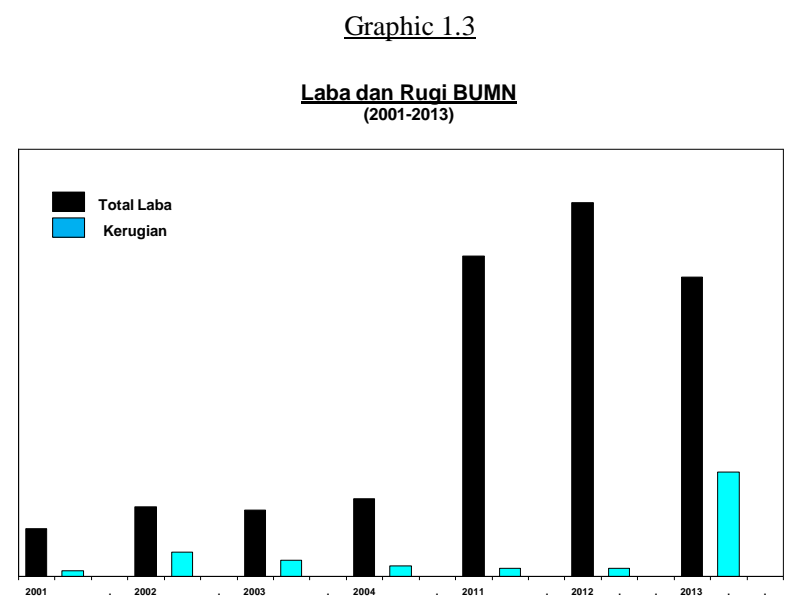

SOEs reform existed to respond to the problem through variety of options. SOEs reform in several countries has been driven by several major issues including of governance 
(corruption), inefficiency of state-owned enterprise, performance in operational/financial dimensions, service delivery (telecommunication), growing number of public employees (effect of nationalization) and growing value of debt (25\%-50\% total outstanding debt). Policy holder need to address the issues and turn it into a plausible policy options to overcome the possible downsides in the future

SOEs reform globally has been predominantly responded by utilizing privatization method. According to Staikouras (2004), privatization constitutes one of the most popular policy options to improve the performance of state-owned enterprise around the globe with more than 100 countries that have privatized their SOEs. Privatization in several countries is to access policies that have been thought to have worked effectively in other jurisdictions.

The objective of SOE reform in the emerging countries is how best to achieve economic and social development in the age of globalization, how to spread more widely the benefit and mitigate the potential negative impacts of international economic integration and how to alleviate poverty so that larger numbers of people can participate in productive activities and gain access to social services essential for human development.

\section{State of the Art dan Novelity}

The discourse related to SOEs reform both conducted institutionally or individually has been evolving for a quite long of periods espesially in regard to the ideal role od SOEs as the public value and business value creator. Nevertheless, the focus of the research is still focusing predomintantly on the business value creation rather than public value creation.

The gap are also reflected on the majority of research related to SOEs that the crtical part of SOEs reform is the improvement of business performance that lead to the improvement of public service through privatization (World Bank, 1995; Toto, 2010; Irianto, 2004: Yusroni, 2007 and Astami \& Neilson, 2010). On the other hand, study on public value creation is limited to bureaucracy and government (Moore,1995; Silver, 1998; Mulgan, 2002) or public value creation in specific field such as enterpreunership (Soeling, 2016)

This research is expected to contibute to the theory and also to the practice and policy in order to improve the role of SOEs. The contribution is dedicated to knowledge in administrative science, reform and public value creation. The differentiation compare to other research related to SOEs are the focus of public value creation during SOEs reform and -in addition to that - the period of research covered during the era post new oder/Soeharto (1998-2016). $\underline{\text { Tabel } 1.1}$

Previous research related to SOEs and value creation

\begin{tabular}{|c|c|c|}
\hline$\underline{\text { SOEs Reform }}$ & Business value Creation & Public Value Creation \\
\hline$\underline{\text { New Order and }}$ & World bank (1995) & $\begin{array}{c}\text { Moore (1995), Stiver } \\
\text { before }\end{array}$ \\
\hline$\underline{\text { Post new order }}$ & $\begin{array}{c}\text { Aivizian (2002), Toninelli } \\
\text { (2000), Yasin (2003), }\end{array}$ & Mulgan (2002), Marjana \\
& $\begin{array}{c}\text { (1992), Soeling (2016) - } \\
\text { Staikoras (2004), Mcleod }\end{array}$ & enterpreneurship \\
& $\begin{array}{c}\text { (2002)Wicaksono (2008), } \\
\text { Toto (2010), Irianto }\end{array}$ & \\
& (2004), Staikoras (2004), & \\
Chang (2007), Yusroni & \\
& (2007) dan Astami \& & \\
& Neilson (2010). & \\
\hline
\end{tabular}

\section{Research Interest:}

The research part of the paper has interest to enrich the concept of public value (Moore, 1995) a theory that has been introduced and used widely in bureaucracy (Moore, 2015) but uniquely in this research will be adopted in the area of SOEs. The research also plan to elaborate the extension of the concept of TIMM (PWc, 2015) and Creating Shared Value (Porter, 2011) in the context of Indonesia.

\section{Problem Solving:}

The research limit the scope of SOEs to the event of Reform that has been experienced by Indonesia for several periods during old order until post new order era. instead of to cover overall universe of SOEs. The outcome is expected to be used and exercised as a learning experience factor for the future especially in the case of SOEs reform. Eventually, the research plan to introduce Business-Societal Value Creation Matrix as a tool to use the application of public value creation concept in practice.

\section{THEORETICAL FRAMEWORK}

\section{$\underline{\text { SOEs Reform }}$}

In general, reform exists to respond to existing problems and to improve current landscape especially when the state experience problem like crisis and also leadership transition (Poliit and Bouckaert, 2001). In addition to that, reform is also 
an effort to optimize performance of individual, groups or institutions (Caiden, 1969). SOEs is inseparable institution within public sector through the public service objective. Therefore, any reform in public sector will have impact to the SOEs and vice versa.

In the case of SOEs, the core issues during reform predominantly are the abuse of power, low productivity, unfocus operational activity (Hill, 2000), low quality of public service and unstreamed organization structure (Chang,2007), improvement of corporate governance (Wicaksono, 2008). At the macro level, SOEs reform is needed to support the improvement of bottleneck in economy, to reduce pressure on state budget (Yasin,, 2003) also to support development and economic recovery post crisis (Forfas, 2008). Specifically, in the developing countries, the objective of SOEs reform is about how to achieve social and development objective in the era of globalization, how to widely spread the risk and advantage of economic integration and to reduce poverty level in general whereas through SOEs, public can actively participate on productive initiative and gather welfare access essential in the human development (World Bank, 2010).

There are various reform options that can be conducted, among other are restructuring, merger, acquisition, operational partnership and private participation through go public and strategic sales (privatization) (Mardjana, 1992), corporatization (Aivizian, 2002) or even nationalization of private or multinational company (Toninelli, 2000). Nationalization of significant of private banks in the era of finansial crisis in 1997 has given birth to a institution called BPPN (Badan Penyehatan Perbankan Nasional) established to become foundation of financial sector solidity today.

Farazmand (2001) emphasize the importance of exploring various SOEs reform type as privatization is not the only one solution as SOEs problem will be different from country to another country and so do the result of privatization. World Bank (1995) conducted a survey and reported a mix performance of the reform through privatization in different jurisdictions. There are three categories of results where countries are regarded better performers (Chile, Republic of Korea and Mexico), mixed or medium performer (Egypt, Ghana, Philipines) and poor performers (India, Senegal and Turkey).

It can be seen that privatization is not always the solution to address SOEs problem especially in the case of "public value" delivery. Not to mention the "moral hazard" resulting from the process in some cases including in Indonesia (Mcleod, 2002). Aivizian, Ge, Qiu (2002) offer the idea of corporatization as one of the reform alternative exercised internally with minimum intervention from outside in order to improve the practice of corporate governance. This option is working smoothly in China signed by the significant contribution to the state budget and also efficiency improvement .
The debate on the reform option has been taking place for quite some time, however the focus is still on the business value creation (efficiency, effectivity and economy). SOEs has gone through a long period of reform with different emphasize- old order (nationalization), new order (restructuring and privatization), reform order (profitisasi) and currently through strengthening synergy among SOEs (Holding). They are predominantly consist of various initiative to increase business performance. It is time to reflect on the function of SOEs for public service obligation (PSO) where public interest become central point of SOEs reform without reducing professional judgement and business interest as a requirement to sustain the instituion. More importandly when the official of ministry mentions recently on the limitation of SOEs role in carrying task of public service and public empowerment (Alloy, 2017). Mardjana (1992) has done research to investigate the public role in both old order and new order, nevertheless the dynamic development in the era of post new order need extended research to picture the current condition .

\section{$\underline{\text { Public Value }}$}

SOEs are entities located both in public and private/business domain. Therefore, they have dual objective in legislation both the catalyst for public and business value creation. Framework of "public value" is needed to focus on the interest of the users and stakeholders. Public value refers to the value created by government through services, laws regulations and other actions. Value and high level of choices of public policy are made by governments but public references are at the heart of public value theory because in democracy only the public can determine what is truly valuable (Mulgan, 2002).

According to King and Stiver (1998), government belongs to citizen so that public administrator should focus their responsibility to serve and empower citizens. Citizens are no longer customer of public services. Instead, they are a producer and designer of public policy. In the case of SOE reform, through the framework, what makes public service distinctive, according to Moore, is that they involve claims of rights by citizens to service that are publicly provided because they are authorized and funded when using state-owned asset such as authority and money approved by public which is including any policy option linked to the effort to improve SOEs, it should be directed to the public's interest both wholly or partly and other stakeholder.

Which policy will achieve the desired purposes most effectively? Answering the question is the reason behind of policy analysis and foundation of good policy advisory (Scott and Karen, 2010). According to Moore (1995), the purpose of policy is to tell a story about creating public value, how government may exercise its authority (role) in developing programs (instruments) to serve public purposes (intended results). 
SOEs are perceived as the arm length of government especially on the execution of development program. Therefore, the performance of SOEs are the reflection of government's performance. The poorly ranked performance of SOEs have created a perception of how incompetent the government is in implementing policy (McLeod, 2005) and lead to the minimum public value creation In some SOEs that has been considered a success story, the performance is merely limited to the "business" performance rather than "public service" performance.

Research on public value creation has been conducted by government but have not touched the entity like SOEs even though SOEs is part of machinery of government. The benefit of public value concept is to give indication of a successful public service and bring testable model.

\section{$\underline{T I M M}$}

TIMM (Total Impact Measurement and Management) is a concept to measure how far public value created in enterprise developed by Pricewaterhouse Cooper (2015). The framework is a comprehensive approach covering dimension of social, environmental and economical from what an enterprise to achieve. The expected outcome from applying the framework are sustainable growth through high quality of public service, enviromentally friendly business model and the creation of innovation, employment and good perception

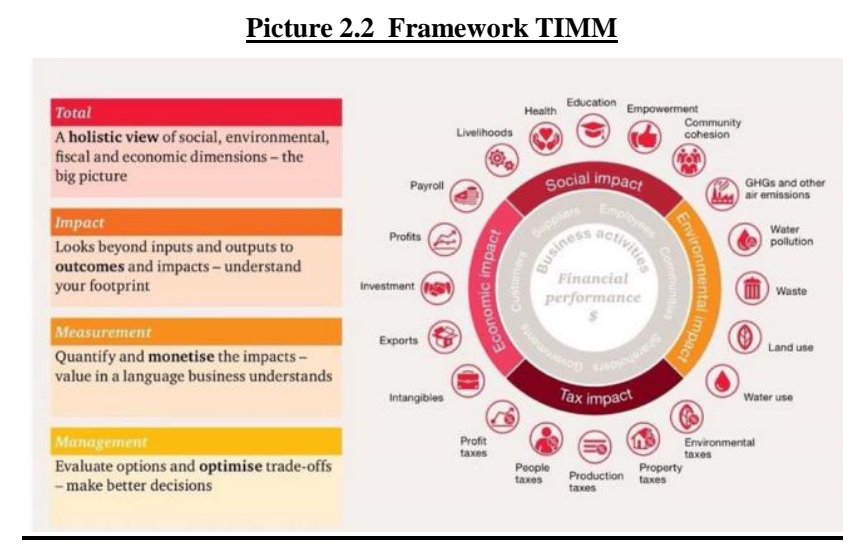

The framework wil place existing SOEs within matrix Business Value-Public Value creation and easily compared from one to another (picture 2.3)
Picture 2.3

Matrix Business-Public Value Creation

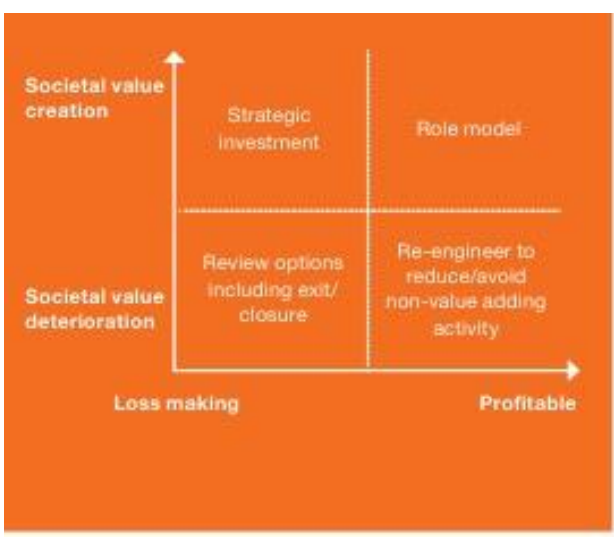

\section{METHODOLOGY}

The research will utilize Soft System Methodology (Checkland, 2006) to gather comprehensive and contextual picture related to reform in order to bridge the transformation of SOEs in regard to public value creation. Based on dual imperative role of SSM Methodology, this research is expected to enrich and develop existing theory or model in public value concept. In addition to that, this research is also to find solution to improve the public role of SOEs

At the implementation stage, research technique will be conducted initially through general interview with several informants and followed up by in-depth interview and FGD to informants who has relevant characteristics but different backgrounds including of the policy makers who are directly or indirectly related to SOEs, communities or groups deal with SOEs program. Meanwhile, the secondary data will be gathered through reports, journals and books related to SOEs reform and public value creation.

\section{DISCUSSION}

Based on initial discussion during May 2017 with policy holders both at the ministry of SOEs and SOEs officials, there is an indication of situation considered as problem according to the concept of public value (Moore, 1995), involving three elements of public value creation which are authorising environment, public value capability and outcome. The situation can be viewed on the following rich picture (picture 4.1) 


\section{Picture 4.1. Rich Picture}

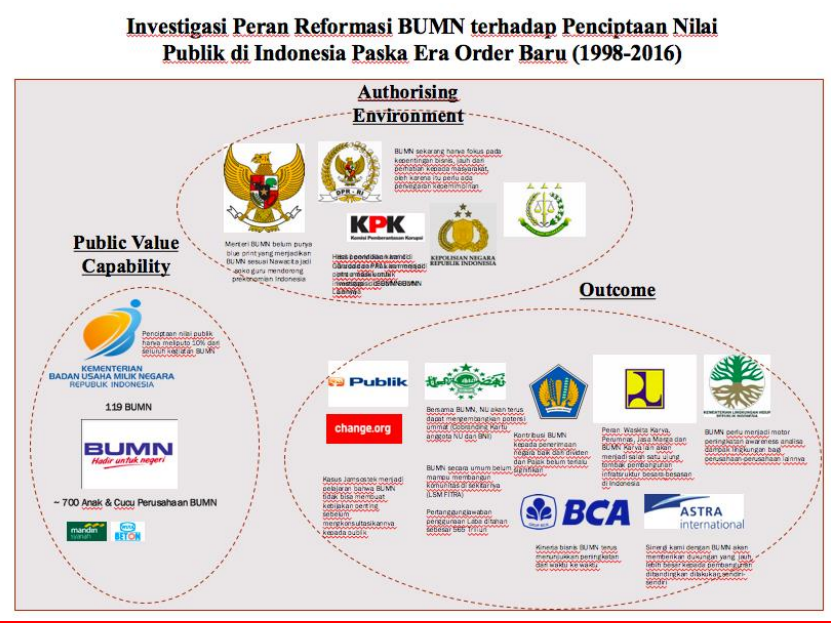

The rich picture above describe the problem and complexity or SOEs role and function. From economic perspective, the development of SOEs in Indonesia has been progressively increasing over time. Currently, the number of SOEs grow to 139 corporations and more than 700 subsidiaries with total aset of 5,000 Trillion Rupiahs or equivalent with $50 \%$ of Gross Domestik Product (GDP) and employ more than one million people. The grow of SOEs both number, total assets, profitabilty and employability perceived as the increase of SOEs competitiveness compare to the other type of enterprise both private and multinaational. Moreover, SOE is currently the most dominant player in certain industry such as infrastructure (Rosan, 2017).

However, on the other hand, in the context of role of public value creation is considered stagnant. No more than $10 \%$ activity and effort from SOEs dedicated to such role (Aloysius K. Ro, 2017). Politicians convey the finding as the message of how weak attention of SOEs to public service (Hasto, 2016). Significant public value creation is also expected from other ministries or quasi government institution through supporting financing of development either from tax or dividend (ministry of finance), more atention to public health and environment protection (ministry of health and environment) and governance or combatting corruption issues (Commision of Corruption Eridication/KPK). Recent legal conviction of corruption involves CEO of major SOEs in Indonesia (PT Garuda and PT PAL among other) is a signal that governance still a big home work to be solved by policy makers surrounding SOEs.

Refer to Aloysius K. Ro (2017), the other critical issues that arise is also expectation for any SOEs to implement both public and business value creation regardless type of SOEs, where in the past the dual function implemented by different type of SOEs such as Perum (Perusahaan Umum) for public service and PT (Perusahaan terbatas) for business performance
SOEs reform found several factual problems in delivering public value creation:

1. Inabsence of specific policy to require SOEs implement and achieve certain part of public value creation.

2. Disconnetion of government grand strategy with the SOEs internal policy.

3. Strategic decision making process (actors, decision typology and decision making)

4. Inabsence of indicators that can be utilized to become guidance to implement public vakue creation.

5. Unclear standpoint of government to stimulate and accelerate SOEs public value creation.

6. SOEs politicking

Root Definition of the research can be described as "A system that can be utilized by SOEs to achieve optimal public service objective (P) through policy, organizational arrangement and improvement of operational capability (Q) in order to create role model of SOEs that can balance public and business value creation (R)".

To clearly define the problems, researcher use technique called CATWOE (Customers, Actors, Transformation Process, World View, Owners, Environmental Constraints). In this research, CATWOE in SOEs public value creation is elaborated in the table as follow:

In the following stage, as enabler to research process, researcher build conceptual model framework to conduct research as has been previously stated, to frame SOEs reform as part of reform theory (Cayden,1969; Poliitt dan Boukaert, 2011), Public Value (Moore, 1995) and TIMM (PWc, 2015).

\section{POLICY RECOMMENDATION}

Several key recommendations for improvement at the organizational and operational level in regard to the implementation of SOEs public value creation policy:

1. The reiteration of leadership commitment towards the direction of SOEs in line with the spirit of legislation to create significant contribution to public value creation

2. The amendment of legislation as a tool to strengthen SOEs obligation to obey the requirement to deliver public service at the operational level .

3. The SOEs organization both at the level of ministry (special staff) and SOEs itself (board of director or independent board commisioner) need to have designated function to oversee the implementation of public value creation delivery.

4. SOEs needs to have designated strategic management policy in the context of public value creation

5. Operational guidance for public value creation is needed to support vision and mission of SOEs 
during the Old Order and New Order Governments. ASEAN Economic Bulletin 9 (2): 187-206.

6. The necessity of policies to be sosialized intensively to the main stakeholders (public, related ministries, media, academics) so that awareness will be root down to the SOEs ecosystem.

7. Evaluation is required to map position of SOEs in delivering the implementation of public value creation from time to time, supported by mechanism of reward and punishment to make sure that the policy plausible to be implemented at the oprational level.

\section{CONCLUSION}

SOEs has gone through a long period of effort and struggle to increase their quality and performance through various type of reforms, different approach in different eras. Old order with the "nationalization" approach, new order (restructuring and privatization) and reform order (profitisation ) and currently in the post reform order (Holding). Nevertheless, the reform process is viewed as lack of value delivered to public as a whole. Therefore, to anticipate opportunity to do reform in the future, it is necessary to improve function of public service obligation from many fronts such as amandement of legislation, organizational improvement and clear guidance supported by sufficient conceptual model.

\section{REFERENCES}

[1]. Abeng, T (2001) Indonesia, Inc. Privatising State-Owned Enterprise. Times Academic Press, Jakarta.

[2]. Aivazian, V. and Qiu,J. (2002) Can Corporatization Improve the Performance of State Owned Enterprise even without Privatization? Paper Presented at the University of Toronto.

[3]. Astami, E. and Neilson, J.(2010) The Effect of Privatisation on performance of state-owned-enterprises in Indonesia. Asian Review of Accounting 18(1): 5-19

[4]. Batley, R. and Larbi, G.A (2004) The Changing Role of Government: The Reform of Public Service in Developin Countries. Palgrave Macmillan

[5]. Chang,H.J.(2007) State-owned Enterprise Reform: National Development Strategies. NewYork, NY.

[6]. Checkland, P. and Poulter, J. (2009), Learning for Action, A Short Definitive Account of Soft Systems Methodology and its use for Practitioners, Techers and Students, John Wiley \&Sons.

[7]. Checkland, P. and Scholes, J (1990), Soft Systems Methodology in Action, John Wiley \& Sons.

[8]. European Commission (2009) Public Sector Reform: An Introduction. Concept Paper, Brussell.

[9]. Gallop G. (2007) 'Towards a New Era of Strategic Government', chapter 7 in J. Wanna (ed) A Passion forPolicy: Essays in Public Sector Reform, Canberra, ANU e-Press.

[10]. Irianto, G.(2004) A Critical Enquire into Privatisation of StateOwned Enterprise: The Case of PT Semen Gresik (Persero) Tbk. Indonesia. Thesis, University of Wollongong

[11]. Karen,B. and Scott,C.(2010). Adding Value to Policy Analysis and Advice. Sydney, UNSW Press.

[12]. Kementerian Badan Usaha Miliki Negara (2015) Rencana Strategis Kementerian BUMN 2015-2019. Jakarta

[13]. Mardjana,I.(1992) Policy Changes in Indonesian Public Enterprises
[14]. McLeod,R.(2005) Public Sector Lesson for Public Sector Reform in Indonesia. Indonesia Project, Economics department, The Australian National University.

[15]. McLeod, R.(2002) Privatization Failures in Indonesia. Indonesia Project, Economics Department, The Australian National University.

[16]. Ministry of State-owned enterprise, Republic of Indonesia (2010).Strategic Planning Book 2009-2014. Jakarta, Indonesia.

[17]. Moore, H.M. (1995). Creating Public Value: Strategic Management in Government. Cambridge, Harvard University Press.

[18]. Mulgan, G. and Kelly, G. (2002).Creating Public Value An analytical Framework for Public Service Reform.United Kingdom, Strategy Unit Cabinet Office.

[19]. Prakoso, H, B.(2016) Public Value Creation dalam praktik kewirausahaan sosial di ponpres agribisnis alittifaq Bandung, Disertasi.

[20]. Pricewaterhouse Cooper (2015) State-Owned Enterprises: Catalyst for Public Value Creation? London, United Kingdom

[21]. Reddel, T. (2002). Beyond Participation, Hierarchies, Management and Markets: New Governance and Place Policies.Australian Journal of Public Administration 61(1): 50-63

[22]. Soeling,P. (2014). Keterikatan Pegawai: Anteseden dan Konsekuensi pada Bandar Udara Ngurah Rai, Disertasi

[23]. Staikoras,P.(2004). Structural Reform Policy: Privatisation and Beyond- The Case of Greece. European Journal of Law and Economics 17(3): 373-398.

[24]. Wicaksono,A.(2008) Indonesian State-Owned Enterprises: The Challenge of Reform. Southeast Asian Affairs 6 (2): 146-167.

[25]. World Bank (1995) Bureaucrats in Business: The Economics and Politics of Government Ownership. New York, Oxford University Press.

[26]. Yasin, M (2005) Reformasi BUMN: Upaya Menata Ulang Peran Pemerintah dalam Dunia Usaha. Paper presented at the Seminar and Lokakarya Nasional "Strategi Reformasi BUMN" UGM, Yogyakarta

\section{Short Bios}

Ubaidillah Nugraha is currently a Doctoral student at the Faculty of Administrative Science (University of Indonesia), lecturer at the undergraduate and postgraduate program (Bina Nusantara University) and Independent Committee Member for HSBC Bank. He previously was Managing Director/CFO for Trimegah Securities and Vice President for Bank Mandiri Tbk. He graduated from University of Indonesia, Faculty of Economics and earned his postgraduate degree in Public Management from School of Government, Victoria University, New Zealand.

Previous papers:

2017 1st Indonesia Development Conference (Bappenas) Jakarta, Indonesia

Paper: Financial Literacy and Finansial Inclusion in Indonesia

$20166^{\text {th }}$ International of Journal of Anthrophology Indonesia Jakarta, Indonesia.

Paper: "A Necessary Given" or "Social Illness" in Society Public Policy Perpective on Inequality

2014 11th Northeastern Conference on Indonesia, Yale University New Haven, USA

Paper: Strategic Management in Government

2013 CFO Conference: Current landscape of Regional Fin.Market Singapore

Topic: The Role of CFO in the Indonesian growing market

2011 International Conference on Financial Engineering \& Risk Mgt. Bandung.

Paper: Quantitative Trading in Indonesian Capital Market. 